Tropical Journal of Pharmaceutical Research January 2016; 15 (1): 101-106

ISSN: $1596-5996$ (print); 1596-9827 (electronic) (c) Pharmacotherapy Group, Faculty of Pharmacy, University of Benin, Benin City, 300001 Nigeria.

All rights reserved.

Available online at http://www.tjpr.org Original Research Article

http://dx.doi.org/10.4314/tjpr.v15i1.14

\title{
Dual Mechanism of Action of Resveratrol in Notch Signaling Pathway Activation in Osteosarcoma
}

\author{
Xin Liu', Qiao Zhang ${ }^{2}$, Ye $\mathrm{Li}^{2}$, Dong-Xu Zhao ${ }^{2}$ and Rui Gu ${ }^{2 \star}$ \\ ${ }^{1}$ Department of Stomatology, ${ }^{2}$ Department of Orthopedics, China-Japan Union Hospital of Jilin University, Jilin 130033, China \\ *For correspondence: Email: guruigr@hotmail.com; Tel/Fax: 0086-431-84995114
}

Received: 17 August 2015

Revised accepted: 12 December 2015

\begin{abstract}
Purpose: To demonstrate the effect of resveratrol on Notch signaling in MG-63 and U2OS osteosarcoma cell lines.

Methods: Cell Counting Kit 8 reagent was used to analyze cell proliferation while TRIzol® reagent was employed for the extraction of total RNA. High Capacity cDNA reverse transcription chain reaction kit was used to transcribe $2 \mu \mathrm{g} R \mathrm{NA}$. Western blot analysis was performed to examine Hes1 and Hey1 expression.

Results: The results revealed that resveratrol treatment exhibited dual mechanisms of action on the activation of Notch signaling in osteosarcoma cells. The osteosarcoma cell lines, MG-63 and U2OS, when exposed to $20 \mu \mathrm{M}$ concentration of resveratrol for $48 \mathrm{~h}$ showed significant toxicity compared to untreated cells. However, $30 \mu \mathrm{M}$ concentration of resveratrol induced higher toxicity which was lethal to cell growth. The results from RT $q P C R$ and Western blot data revealed a concentration-dependent effect of resveratrol on the expression of Notch signaling genes including Hes1, Hes5, Hey1, Hey2 and HeyL in U2OS cells. Treatment of U2OS cells with $20 \mu \mathrm{M}$ concentration of resveratrol for $48 \mathrm{~h}$ induced a marked increase in the expression of Hes1, Hes5, Hey1, Hey2 and HeyL mRNA compared to the untreated cells. However, at a concentration of $30 \mu \mathrm{M}$, resveratrol inhibited the activation of Notch signaling pathway. This was evident by a decrease in the expression of Hes1, Hes5, Hey1, Hey2 and HeyL, Notch signaling target genes.

Conclusion: Resveratrol plays an important role in the activation of Notch signaling pathway and may be of therapeutic benefit in the treatment of osteosarcoma.
\end{abstract}

Keywords: Osteosarcoma, Dual action mechanism, Notch signaling pathway, Toxicity, Cell growth inhibition

Tropical Journal of Pharmaceutical Research is indexed by Science Citation Index (SciSearch), Scopus, International Pharmaceutical Abstract, Chemical Abstracts, Embase, Index Copernicus, EBSCO, African Index Medicus, JournalSeek, Journal Citation Reports/Science Edition, Directory of Open Access Journals (DOAJ), African Journal Online, Bioline International, Open-J-Gate and Pharmacy Abstracts

\section{INTRODUCTION}

Osteosarcoma one of the frequently detected malignant bone tumors in adolescents and children is associated with enhanced local growth and metastasis [1]. In the USA alone, more than 400 new cases of pediatric osteosarcoma are detected every year [2]. The commonly used treatment strategies for osteosarcoma include chemotherapy and surgical excision, but the rate of prognosis is very poor [3]. Therefore, efforts for discovery and screening of novel molecules for osteosarcoma treatment are constantly being performed throughout the globe. During the last three decades various molecules have been developed for the treatment of osteosarcoma which led to overall survival rate of more than 50 $\%$. Some of these molecules include methotrexate, resveratrol, ifosfamide cisplatin, 
and etoposide [4]. However, it has been reported that patients with metastatic or recurrent tumors show poor prognosis $[5,6]$. Therefore, it is believed that knockdown of signaling pathways can provide promising results for the treatment of osteosarcoma.

The process of proliferation, apoptosis and cell differentiation in various types of cancers is regulated by Notch signaling pathway [7-9]. It is reported that Notch receptors interact with the corresponding ligands after cleavage in the presence of proteolytic enzymes. These alterations induce the secretion of intracellular domain of Notch which is translocated to the nucleus where it complexes leading to the activation of transcription specific target genes $[10,11]$. These target genes include hairy and enhancer of split (Hes) and Hes related with YRPW motif (Hey). Down-regulation of the activity of Notch genes has been detected in various malignancies like colon [12,13], pancreatic [14,15] and cervical [16] cancer. Furthermore, various studies have demonstrated reduced activity of Notch in osteosarcoma $[17,18]$. Therefore, the present study was designed to investigate the effect of resveratrol on the activity of the Notch signaling pathway in U2OS osteosarcoma cell lines.

Resveratrol has shown promising results in the suppression of cellular events involved in the beginning and progression of tumors in several types of cells lines $[19,20]$. It also increases the immunity of mice by promoting the expression of cytokines including interleukin (IL)-12 and interferon (IFN)- $y$ [21]. In addition, resveratrol treatment induces inhibition of cell growth and proliferation in breast carcinoma cell lines [22]. The synthetic derivatives of resveratrol have also been shown to possess potent activity against tumor cell lines including MCF-7 human breast adenocarcinoma cell line $[23,24]$. The present study demonstrates the effect of resveratrol on Notch signaling pathway activation in MG-63 and U2OS, osteosarcoma cell lines. The results revealed that resveratrol treatment exhibited dual effect on the activation of Notch signaling pathway.

\section{EXPERIMENTAL}

\section{Reagents}

Resveratrol was obtained from Sigma (St. Louis, $\mathrm{MO})$ and was dissolved in dimethyl sulfoxide (DMSO, Sigma) to prepare the stock solution.

\section{Cell lines and culture}

Human osteosarcoma cell lines MG-63 and U2OS were obtained from the American Type Culture Collection (ATCC, Rockville, MD, USA). The cells were grown in DMEM with $10 \%$ FBS and cultured in $5 \% \mathrm{CO}_{2}$ atmosphere at $37{ }^{\circ} \mathrm{C}$. The viability of the cells was analyzed using trypan blue staining (Invitrogen Life Technologies).

\section{Cytotoxicity assay}

MG-63 and U2OS osteosarcoma cells were distributed at a density of $2 \times 10^{5}$ cells per well onto the 96 well culture plates. To each of the well different concentrations of resveratrol were added and the cells were cultured for $48 \mathrm{~h}$. The control cells were treated with DMSO alone and then incubated for $48 \mathrm{~h}$. After incubation, $20 \mu \mathrm{L}$ of the Cell Counting Kit 8 reagent Sigma (St. Louis, MO), was added to each well. The cells were again incubated for $1 \mathrm{~h}$ at $37{ }^{\circ} \mathrm{C}$ under humidified atmosphere of $5 \% \quad \mathrm{CO}_{2}$. The microplate reader (Thermo Fisher Scientific, Waltham, MA, USA) was used to measure the optical density of each well at $465 \mathrm{~nm}$.

\section{Quantitative polymerase chain reaction (qPCR)}

From the resveratrol treated or untreated cells, total RNA was extracted using TRIzol® reagent (Invitrogen Life Sciences, Carlsbad, CA, USA) according to the manufacturer's instructions. The High Capacity cDNA Reverse Transcription kit (Applied Biosystems, Inc, Foster City, CA, USA) was used to transcribe $2 \mu \mathrm{g}$ RNA samples to cDNA according to the manual protocol. QuantiTect SYBR Green PCR kit (Qiagen, Tokyo, Japan) was used for the quantification of transcripts by GPCR whereas the analysis was performed using Applied Biosystems $₫ 7500$ Fast Real Time PCR system (Applied Biosystems Inc.). The PCR reactions were carried out at 95 ${ }^{\circ} \mathrm{C}$ for $10 \mathrm{~min}$, then 40 cycles of $95^{\circ} \mathrm{C}$ for $30 \mathrm{sec}$ and $60{ }^{\circ} \mathrm{C}$ for $1 \mathrm{~min}$. The data obtained was then analyzed using $\mathrm{ABI}$ Prism ${ }^{\circledR}$ analysis software (Applied Biosystems, Inc.).

\section{Western blot analysis}

U2OS and Saos 2 cells were washed three times with cold PBS and then treated with $120 \mu$ radioimmuno precipitation assay buffer $[50 \mathrm{mM}$ Tris $\mathrm{HCl}, \mathrm{pH} 6.8 ; 0.1 \%$ SDS, $150 \mathrm{mM} \mathrm{NaCl}, 1 \mathrm{mM}$ EDTA, $0.1 \mathrm{mM} \mathrm{Na}_{3} \mathrm{VO}_{4}, 1 \mathrm{mM}$ sodium fluoride (NaF), $1 \%$ Triton X 100, 1 \% NP 40, $1 \mathrm{mM}$ dithiothreitol, $1 \mathrm{mM}$ PMSF, $1 \mu \mathrm{g} / \mathrm{mL}$ aprotinin, 1 $\mu \mathrm{g} / \mathrm{mL}$ leupeptin and $1 \mu \mathrm{g} / \mathrm{mL}$ pepstatin A] for cell 
lysis. Cell lysates were centrifuged at $12,000 \times \mathrm{g}$ for $30 \mathrm{~min}$ to get the clear supernatant. For the purpose of the determination of the concentration of proteins bicinchoninic acid assay (Sigma Aldrich). The proteins were separated by electrophoresis on SDS polyacrylamide gel and then transferred onto polyvinylidene difluoride membranes. The membranes were blocked with $5 \%$ skimmed milk in buffer $[10 \mathrm{mM}$ Tris $\mathrm{HCl}(\mathrm{pH}$ 7.6), $100 \mathrm{mM} \mathrm{NaCl}$ and $0.1 \%(\mathrm{v} / \mathrm{v})$ Tween 20] for $45 \mathrm{~min}$ at $25^{\circ} \mathrm{C}$. The membranes were incubated with primary antibodies under cold atmosphere overnight. The primary antibodies used were anti Hes1, anti Hey1 and anti $\beta$ actin (BD Biosciences Pharmingen). After incubation, Tris buffered saline and Tween 20 washed membranes were incubated with the secondary antibodies for $2 \mathrm{~h}$. The proteins were analyzed by semi quantitation using Tanon Gel Imager system (Tanon, Shanghai, China).

\section{Statistical analysis}

Analysis of the obtained data was performed using a statistical software (SPSS Inc, Chicago,
IL, USA). All the data are presented as mean \pm standard deviation (SD), and for numerical data analysis, Student's t-test or one-way analysis of variance (ANOVA) was used. Differences were considered statistically significant at $p<0.05$.

\section{RESULTS}

\section{Effect of resveratrol on the osteosarcoma cell lines}

The osteosarcoma cell lines, MG-63 and U2OS were exposed to a range of resveratrol concentrations from 5 to $30 \mu \mathrm{M}$ for various time intervals. The results revealed a concentration and time dependent increase in toxicity to MG-63 and U2OS cells. The concentration at which the resveratrol induced toxicity in both the cell lines was significant compared to untreated cells at 20 $\mu \mathrm{M}$ after $48 \mathrm{~h}(p<0.01$; Fig 1$)$. However, when MG-63 and U2OS cells were exposed to $30 \mu \mathrm{M}$ concentration of resveratrol for $48 \mathrm{~h}$ it induced higher toxicity which was lethal to cell growth ( $p$ $<0.01$; Fig 1).
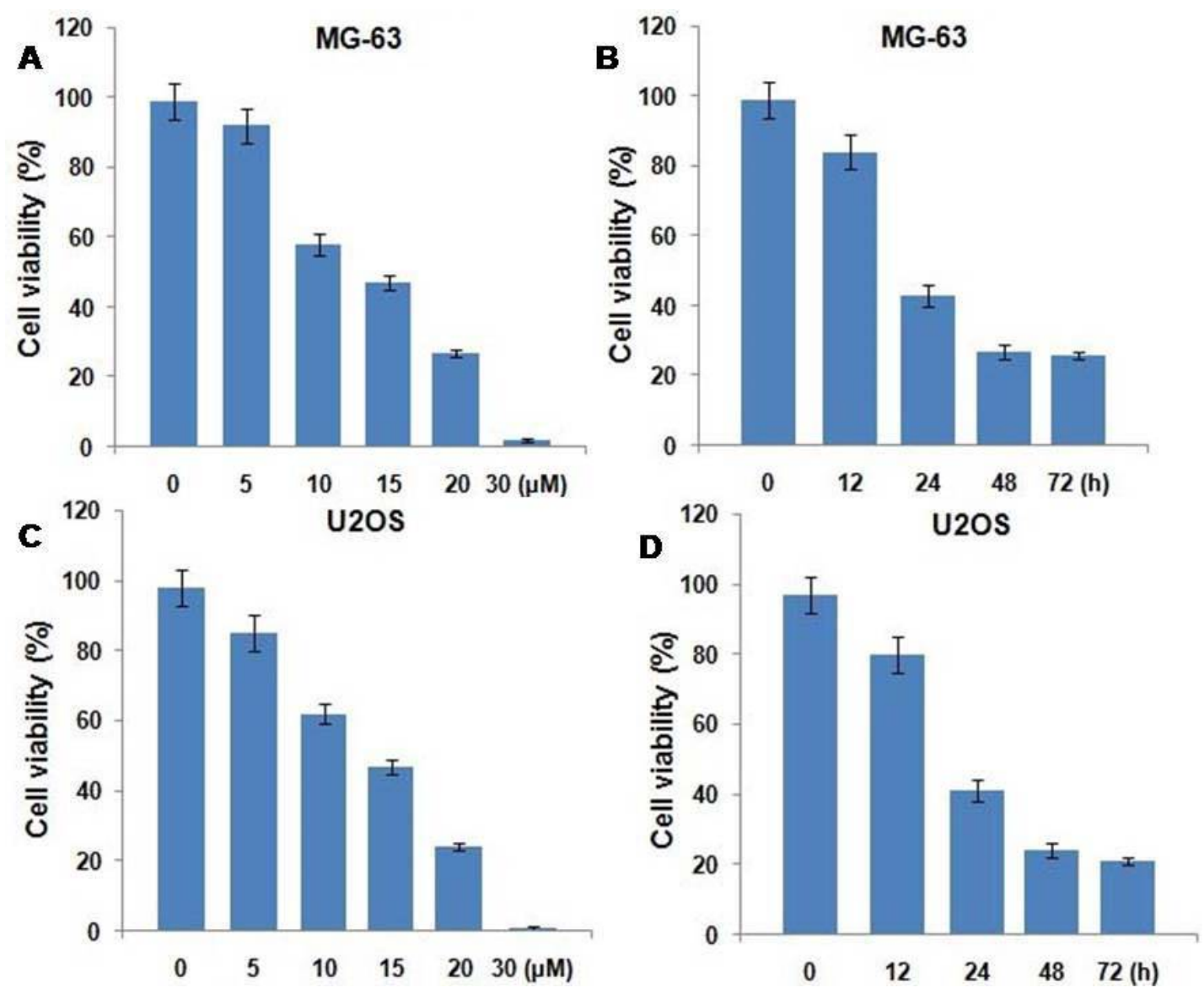

Figure 1: Resveratrol treatment reduces the viability of osteosarcoma cells. MG-63 and U2OS osteosarcoma cells were exposed to different doses of resveratrol for various time intervals 


\section{Effect of resveratrol on the expression of Notch target genes}

We used RT qPCR and western blot analyses to examine the effect of resveratrol on the activation of Notch signaling pathway. The results from RT QPCR analysis revealed a concentration dependent effect of resveratrol on the expression Notch signaling genes including Hes1, Hes5, Hey1, Hey2 and HeyL, in U2OS cells. Treatment of U2OS cells with $20 \mu \mathrm{M}$ concentration of resveratrol for $48 \mathrm{~h}$ induced a marked increase in the expression of Hes1, Hes5, Hey1, Hey2 and HeyL mRNA compared to the untreated cells ( $p$ $<0.05$; Fig 2A). These results were further confirmed using western blot analysis.

\section{Inhibition of Notch target gene expression by resveratrol at high concentration}

Exposure of the U2OS osteosarcoma cells to resveratrol at $50 \mu \mathrm{M}$ concentration led to a marked decrease in the expression of Hes1, Hes5, Hey1, Hey2 and HeyL, Notch target genes $(p<0.05$; Fig 3A). To confirm the inhibitory effect of resveratrol at $30 \mu \mathrm{M}$ concentration western blot analysis was performed. The results from western blot analysis also revealed a significant decrease in the expression of Hes1 and Hey1 genes following $48 \mathrm{~h}$ of the resveratrol treatment (Fig 3B).

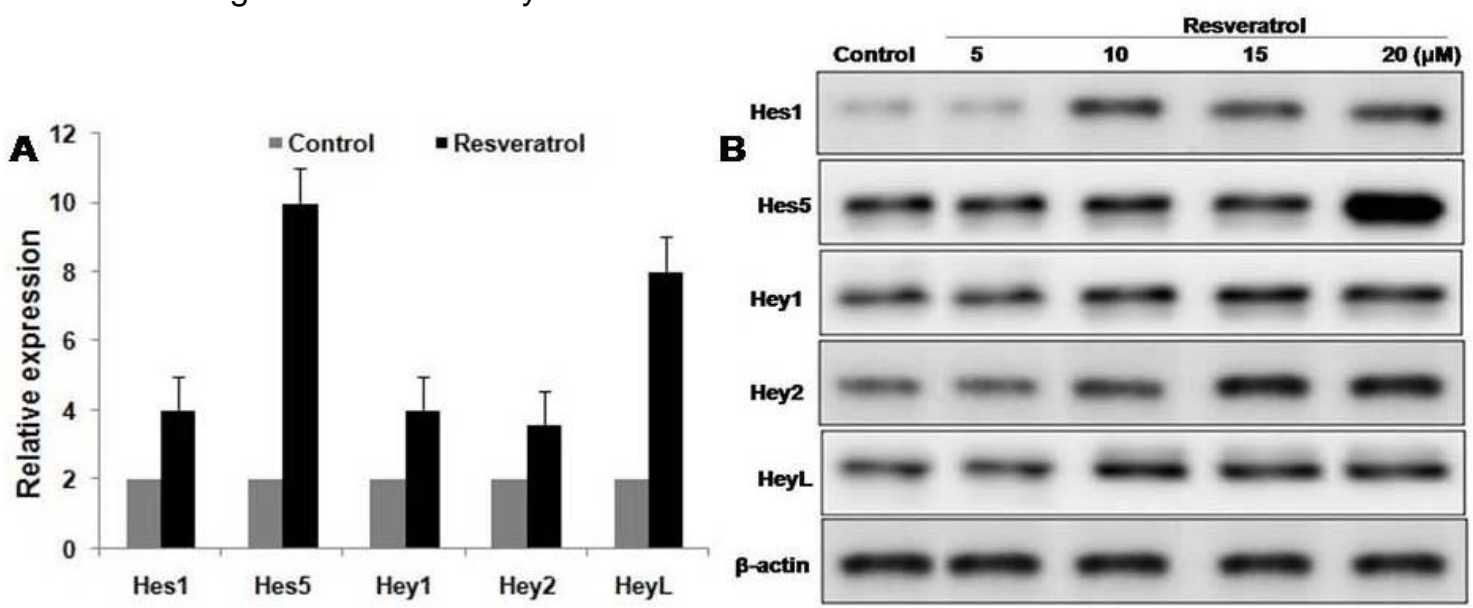

Figure 2: Activation of Notch target genes in osteosarcoma U2OS cells by treatment with $20 \mu \mathrm{M}$ concentration of resveratrol for $48 \mathrm{~h}$. (A) Reverse transcription-quantitative polymerase chain reaction (RT-qPCR) data indicating that resveratrol treatment increased the mRNA expression levels of various Notch target genes. (B) Western blot data demonstrating that resveratrol treatment increased the mRNA and protein expression levels, respectively, of two Notch target genes (Hes1 and Hey1) in a dose-dependent manner. Results are presented as the mean \pm standard deviation of three independent experiments

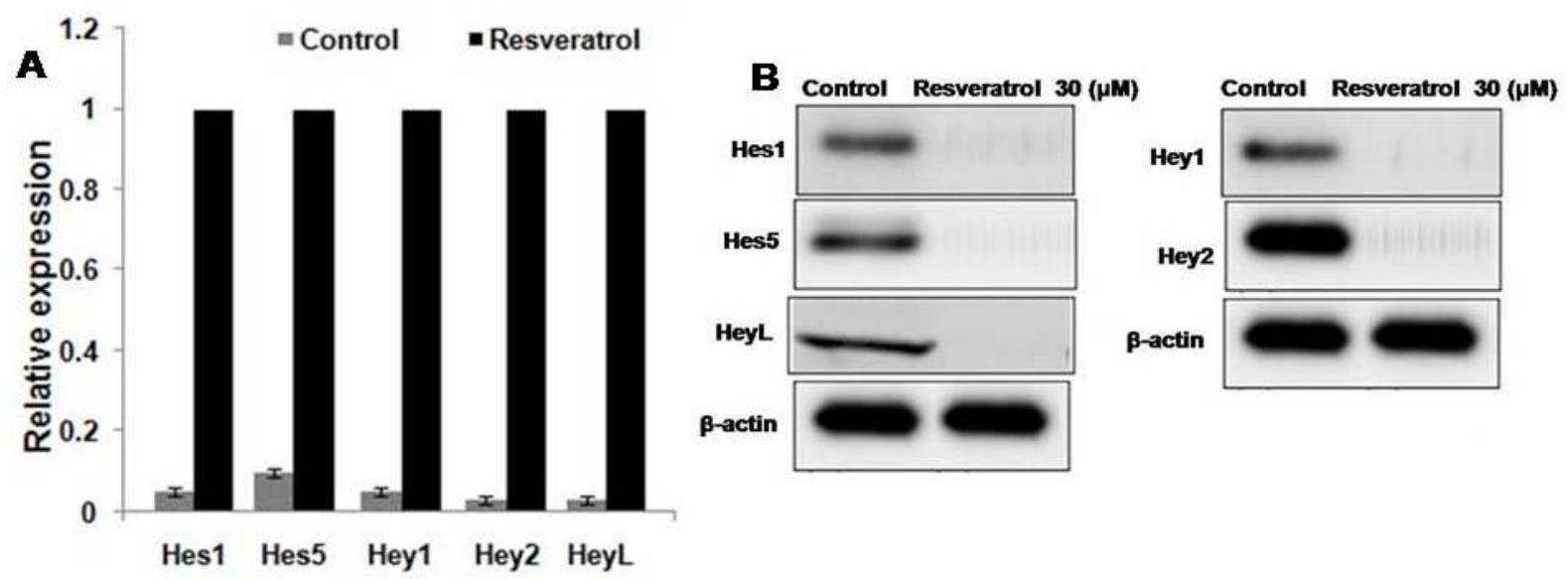

Figure 3: Suppression of Notch target genes in U2OS osteosarcoma cells by treatment with a toxic dose of resveratrol $(30 \mu \mathrm{M})$ for $48 \mathrm{~h}$. (A) Reverse transcription-quantitative polymerase chain reaction (RT-qPCR) and (B) western blot results demonstrated that resveratrol treatment resulted in a significant decrease in Notch target gene expression levels. Results are presented as the mean \pm standard deviation of three independent experiments 


\section{DISCUSSION}

Exposure of the tumor cells to resveratrol led to the suppression of cellular processes associated with the beginning and progress of tumors $[19,20]$. Resveratrol treatment enhances immunity of mice by increasing the expression of cytokines like interleukin (IL)-12 and interferon (IFN)-y [21]. In addition, resveratrol treatment inhibits cell growth and proliferation in breast carcinoma cell lines [22]. The present study demonstrates the role of resveratrol in the activation of Notch activity in osteosarcoma cells. The results from the present study showed that resveratrol induced toxicity in MG-63 and U2OS osteosarcoma cell lines significantly compared to untreated cells at $20 \mu \mathrm{M}$ concentration after $48 \mathrm{~h}$. However, at $30 \mu \mathrm{M}$ concentration, resveratrol induced higher toxicity which was lethal to cell growth.

It is reported that Notch activity leads to the development of tumors in osteosarcoma cells [18]. The activity of Notch1 in osteosarcoma cells plays an important role in the process of tumor cell invasion and tissue metastasis [25]. Studies have been performed which clearly demonstrate that downregulation of Notch signaling pathway inhibits the proliferation rate of cancer cells in vitro and tumor growth in vivo [26].

The present study reveals that resveratrol treatment exhibits a concentration dependent effect on toxicity in osteosarcoma cells. Exposure of the osteosarcoma cells to resveratrol up to 20 $\mu \mathrm{M}$ significantly increased the expression of Hes1, Hes5, Hey1, Hey2 and HeyL, Notch target genes after $48 \mathrm{~h}$. These findings revealed that concentration of resveratrol required for induced activation of Notch signaling pathway is $20 \mu \mathrm{M}$.

However, when the osteosarcoma cells were exposed to higher concentration $(30 \mu \mathrm{M})$ of resveratrol, the expression levels of Notch genes was reduced significantly. Therefore, the data from the present study demonstrates that resveratrol induced cytotoxicity in the osteosarcoma cells at higher doses may be associated with the suppression of Notch signaling pathway.

\section{CONCLUSION}

Resveratrol exhibits dual role in the activation of Notch signaling pathway by promoting its activation at low doses and inhibiting it at higher doses. Therefore, the drug is a potential candidate for the treatment of breast cancer.

\section{REFERENCES}

1. Jaffe N. Osteosarcoma: review of the past, impact on the future. The American experience. Cancer Treat Res 2009; 152: 239262.

2. Chou AJ, Merola PR, Wexler LH. Treatment of osteosarcoma at first recurrence after contemporary therapy: the Memorial Sloan Kettering Cancer Center experience. Cancer 2005; 104: 22142221.

3. Nakase $M$, Inui M, Okumura K, Kamei T, Nakamura $S$, Tagawa T. p53 gene therapy of human osteosarcoma using a transferrin modified cationic liposome. Mol Cancer Ther 2005; 4: 625631.

4. Janeway KA, Grier HE. Sequelae of osteosarcoma medical therapy: a review of rare acute toxicities and late effects. Lancet Oncol 2010; 11: 670678.

5. Gelderblom $H$, Jinks RC, Sydes $M$. European Osteosarcoma Intergroup: Survival after recurrent osteosarcoma: data from 3 European Osteosarcoma Intergroup (EOI) randomized controlled trials. Eur $J$ Cancer 2011; 47: 895902.

6. Bacci G, Briccoli A, Longhi A. Treatment and outcome of recurrent osteosarcoma: experience at Rizzoli in 235 patients initially treated with neoadjuvant chemotherapy. Acta Oncol 2005; 44: 748755.

7. Jang M, Cai L, Udeani GO, Slowing KV, Thomas CF, Beecher CW, Fong $\mathrm{HH}$, Farnsworth $\mathrm{NR}$, Kinghorn $A D$, Mehta RG, Moon RC, Pezzuto JM. Cancer chemopreventive activity of resveratrol, a natural product derived from grapes. Science 1997; 275: 218220.

8. Guruharsha KG, Kankel MW, Artavanis Tsakonas S. The Notch signalling system: recent insights into the complexity of a conserved pathway. Nat Rev Genet 2012; 13: 654666.

9. Bianchi S, Dotti MT, Federico A. Physiology and pathology of notch signalling system. J Cell Physiol 2006; 207: 300308.

10. Fortini ME. Notch signaling: the core pathway and its posttranslational regulation. Dev Cell 2009; 16: 633647.

11. Davis RL, Turner DL. Vertebrate hairy and Enhancer of split related proteins: transcriptional repressors regulating cellular differentiation and embryonic patterning. Oncogene 2001; 20: 83428357.

12. Aranguren $X L$, Agirre $X$, Beerens $M$. Unraveling a novel transcription factor code determining the human arterial specific endothelial cell signature. Blood 2013; 122: 39823992.

13. Jin $H Y$, Zhang $H Y$, Wang $X, X u J$, Ding $Y$. Expression and clinical significance of Notch signaling genes in colorectal cancer. Tumour Biol 2012; 33: 817824.

14. Ungerbäck J, Elander N, Grünberg J, Sigvardsson M, Söderkvist $P$. The Notch 2 gene is regulated by Wnt signaling in cultured colorectal cancer cells. PLoS One 2011; 6: e17957.

15. Mysliwiec $P$, Boucher MJ. Targeting Notch signaling in pancreatic cancer patients' rationale for new therapy. Adv Med Sci 2009; 54: 136142.

Trop J Pharm Res, January 2016; 15(1): 105 
16. Avila JL, Kissil JL. Notch signaling in pancreatic cancer: oncogene or tumor suppressor? Trends Mol Med 2013; 19: 320327.

17. Maliekal TT, Bajaj J, Giri V, Subramanyam D, Krishna S. The role of Notch signaling in human cervical cancer: implications for solid tumors. Oncogene 2008; 27: 5110 5114.

18. McManus MM, Weiss KR, Hughes DP. Understanding the role of notch in osteosarcoma. Adv Exp Med Biol 2014; 804: 6792

19. $M u X$, Isaac C, Greco N, Huard J, Weiss K. Notch signaling is associated with $A L D H$ activity and an aggressive metastatic phenotype in murine osteosarcoma cells. Front Oncol 2013; 3: 143.

20. Aggarwal BB, Bhardwaj A, Aggarwal RS, Seeram NP, Shishodia S, Takada Y. Role of resveratrol in prevention and therapy of cancer: preclinical and clinical studies. Anticancer Res 2004; 24: 2783-2840.

21. Bove K, Lincoln DW, Tsan MF. Effect of resveratrol on growth of $4 T 1$ breast cancer cells in vitro and in vivo. Biochem Biophys Res Commun 2002; 291: 1001-1005.
22. Feng $Y H$, Zhou WL, Wu QL, Li XY, Zhao WM, Zou JP. Low dose of resveratrol enhanced immune response of mice. Acta Pharmacol Sin 2002; 23: 893-897.

23. Song S, Lee H, Jin Y, Ha YM, Bae S, Chung HY, Suh $H$. Syntheses of hydroxy substituted 2-phenylnaphthalenes as inhibitors of tyrosinase. Bioorg Med Chem Lett 2007; 17: 461-464.

24. Jeong SH, Jo WS, Song S, Suh H, Seol SY, Leem SH, Kwon TK, Yoo YH. A novel resveratrol analog, HS-1793, overcomes the resistance conferred by Bcl-2 in human leukemic U937 cells. Biochem Pharmacol 2009; 7: 1337-1347.

25. Hughes DP. How the NOTCH pathway contributes to the ability of osteosarcoma cells to metastasize. Cancer Treat Res 2009; 152: 479496.

26. Tanaka M, Setoguchi T, Hirotsu M. Inhibition of Notch pathway prevents osteosarcoma growth by cell cycle regulation. Br J Cancer 2009; 100: 19571965. 